\title{
Prof. arch. Józef Gałęzowski - Osiedle Uzdrowiskowe na Złotej Górze w Ojcowie
}

\section{J.-Krzysztof Lenartowicz}

\author{
Politechnika Lubelska, Wydziat Budownictwa i Architektury, Samodzielna Pracownia Architektoniczna
}

\begin{abstract}
Streszczenie: Prof. Józef Gałęzowski (1877-1963) był wybitnym przedstawicielem krakowskiej architektury. Obok szeregu znaczących projektów i realizacji architektonicznych, był też autorem kilku większych założeń przestrzennych. Artykuł dotyczy tej jego działalności. W okresie I wojny światowej opublikował $(1915,1916)$ projekty odbudowy wsi i miasteczek polskich. Zniszczenia wojenne zamierzał wykorzystać dla podniesienia standardu w trakcie odbudowy. Celem popularyzacji tej idei zorganizował objazdową wystawę rysunków i makiet oraz odczyty. Założył też Biuro Regulacji Miast w Krakowie i Lwowie (1917). Zaprojektował częściowo zrealizowane osiedla: robotnicze w Brześciu Kujawskim (1912), a w okresie międzywojennym: uzdrowiskowe w Ojcowie (1927) - omówione w artykule; robotnicze w Majdanie k. Stanisławowa (1929) i letniskowe w Bukownie (1933). Wszystkie zostały oparte na modelu miasta-ogrodu.
\end{abstract}

Słowa kluczowe: Józef Gałęzowski, Ojców, osiedle uzdrowiskowe, miasto-ogród

\section{Wprowadzenie}

Prof. arch. Józef Gałęzowski (1877-1963) był wybitnym przedstawicielem krakowskiej architektury i urbanistyki (por. Lenartowicz 2013). Obok działalności dydaktycznej na Akademii Sztuk Pięknych w Krakowie, a po II wojnie światowej, także na Politechnice Krakowskiej, jest autorem szeregu znaczących projektów i realizacji architektonicznych, jak też kilku większych założeń przestrzennych. Jego twórczość urbanistyczna w latach 1912-1918 została opisana przez Lenartowicza (2017). W artykule przedstawiono dzieje projektu z 1927 r. i realizacji Osiedla Uzdrowiskowego na Złotej Górze ${ }^{1}$ w Ojcowie.

\section{Historia}

Malownicza dolina Prądnika w Ojcowie była już w XIX w. znana jako „miejscowość klimatyczna”. Oficjalnie za miejscowość uzdrowiskową uznano Ojców w 1918 r. W 1923 r. założona została Spółka Akcyjna Uzdrowisko Ojców, która miała kierować rozwojem stacji klimatycznej. Wkrótce nad planami rozbudowy uzdrowiska zaczęła przeważać idea ochrony unikalnej przyrody ${ }^{2}$. Plany utworzenia rezerwatu w dolinie Prądnika spowodowały,

1 W „Wykazie ważniejszych prac projektowych" załączonym do życiorysu datowanego 14 marca 1953 r. (w Archiwum Politechniki Krakowskiej) Gałęzowski podał projekt urbanistyczny "Osiedla Letniskowego na Chełmowej Górze w Ojcowie" (podkr. - J-KL). Autor pisał wówczas o swoim projekcie sprzed 25 lat i upływowi czasu należy przypisać pomyłkę w określeniu lokalizacji.

2 Z inicjatywy prof. Władysława Szafera w 1924 r. został określony plan i granice przyszłego rezerwatu, który miał objąć dobra Czartoryskich i własności gminne wzdłuż Doliny Prądnika i Doliny Sąspowskiej. Ojcowski Park Narodowy powstał jednak dopiero w 1956 r. 
że zakłady lecznicze postanowiono zlokalizować powyżej samej doliny. Powstał Komitet Rozbudowy Osiedla Uzdrowiskowego Ojców, którego zadaniem było przygotowanie reorganizacji uzdrowiska i jego zabudowy ${ }^{3}$.

Osiedle przewidziano na zboczach Złotej Góry (458 m. n.p.m.) i na płaskowyżu ciągnącym się od niej w stronę północno-zachodnią do Kolencina (folwarku Dąbrówka), na terenie o powierzchni 100 ha przekazanym Komitetowi przez właścicielkę Ojcowa Marię Ludwikę z Krasińskich księżną Czartoryską ${ }^{4}$. Teren porastał las gospodarczy, stanowiący źródło drewna opałowego dla ogrzewania obiektów w posiadaniu Czartoryskich w Krakowie.

\section{Projekt}

Zadanie przygotowania planu parcelacji terenu i zabudowy uzdrowiskowej przypadło Józefowi Gałęzowskiemu. Rozpoznanie dróg jakimi do Gałęzowskiego poszczególne zlecenia na projekt nie jest celem tego artykułu. Można jednak w tym miejscu zauważyć ciągłość jego kontaktów zawodowych z rodziną Krasińskich, poczynając od projektu dworu w Opinogórze (1908), przez osiedle w Ojcowie (1927), po kościół w Żarkach-Letnisku (1937).

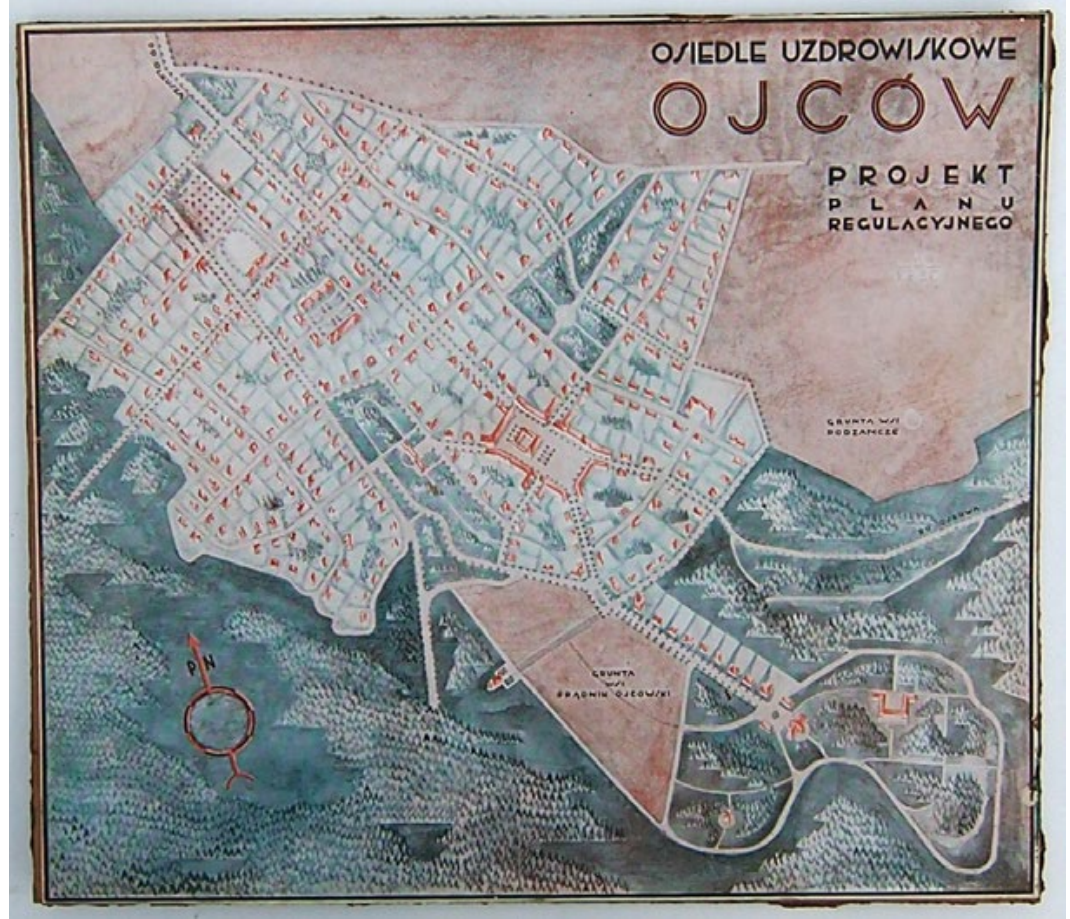

Ryc. 1. Ojców, osiedle uzdrowiskowe, projekt planu parcelacyjnego, Józef Gałęzowski, druk reklamowy, 1927. Dyrekcja Ojcowskiego Parku Narodowego.

Ojców, spa development, plotting plan, J. Gałęzowski, promotional print, 1927. Head Office of Ojców National Park.

Gałęzowski wyobraził osiedle zgodnie z modelem miasta-ogrodu. Na obszarze, którym dysponował poprowadził ulice główne i boczne, mniej więcej pod kątem prostym do siebie, wyodrębnił rynek o proporcji dwóch kwadratów, prawdopodobnie szkołę i kilka terenów zielonych: dwa parki, boisko oraz teren wspólny w środku największego bloku wyznaczonego ulicami. Powierzchnie obsługiwane przez ulice podzielone zostały na działki budowlane, na których narysowane zostały budynki. Wzdłuż styku działek, wewnątrz poszczególnych bloków poprowadzono zielone, prawdopodobnie piesze, ciągi. Prostokątny rynek i wyloty prowadzących nań ulic

3 „Ojców, jako estetyczna i klimatyczna osobliwość przyrody polskiej, nie podzielił dotychczas losu wielu innych naszych uzdrowisk. Położony na granicy dawnego zaboru rosyjskiego, z ogólnych względów strategicznych państw zaborczych Austrji i Rosji, pozbawiony był zupełnie połączeń komunikacyjnych, a przez to zachowany został w stanie swego pierwotnego, przyrodzonego piękna. Z tem łączy się szczęśliwie stan posiadania w Ojcowie, ponieważ Ojców, Kolęcin i Podzamcze jako jeden zwarty kompleks dóbr są własnością Ks. Czartoryskiej, której decyzja umożliwiła wypracowanie racjonalnego i nowożytnego Osiedla. Tylko ofiarności właścicielki i poparciu generalnego Jej Pełnomocnika, Pana Jana Podczaskiego, będziemy mogli w przyszłości zawdzięczać istnienie w Polsce miejscowości klimatycznej, nieustępującej w swych urządzeniach najwytworniejszym uzdrowiskom zagranicznym". Ojców. Rola Ojcowa jako uzdrowiska. Komitet Rozbudowy Osiedla Uzdrowiskowego Ojców, Kraków 1927.

4 Procesy przekształceń uzdrowiska Ojców wyczerpująco przedstawia Mitkowska (1995). 
zostały otoczone zwartą zabudową pierzejową. Na środku rynku znalazł się obiekt usługowy z wewnętrznym dziedzińcem. Wokół placyku we wspomnianym największym bloku pojawia się zabudowa szeregowa jednorodzinna. Zabudowa na pozostałych parcelach to domy wolnostojące.

Projekt koncepcyjny został przedstawiony w postaci barwnego rysunku w skali 1:5000, który został powielony techniką offsetową o dość dużym rastrze ${ }^{5}$. Jest to zbliżona do kwadratu plansza przedstawiająca projekt osiedla w aksonometrii dimetrycznej (Ryc. 1).

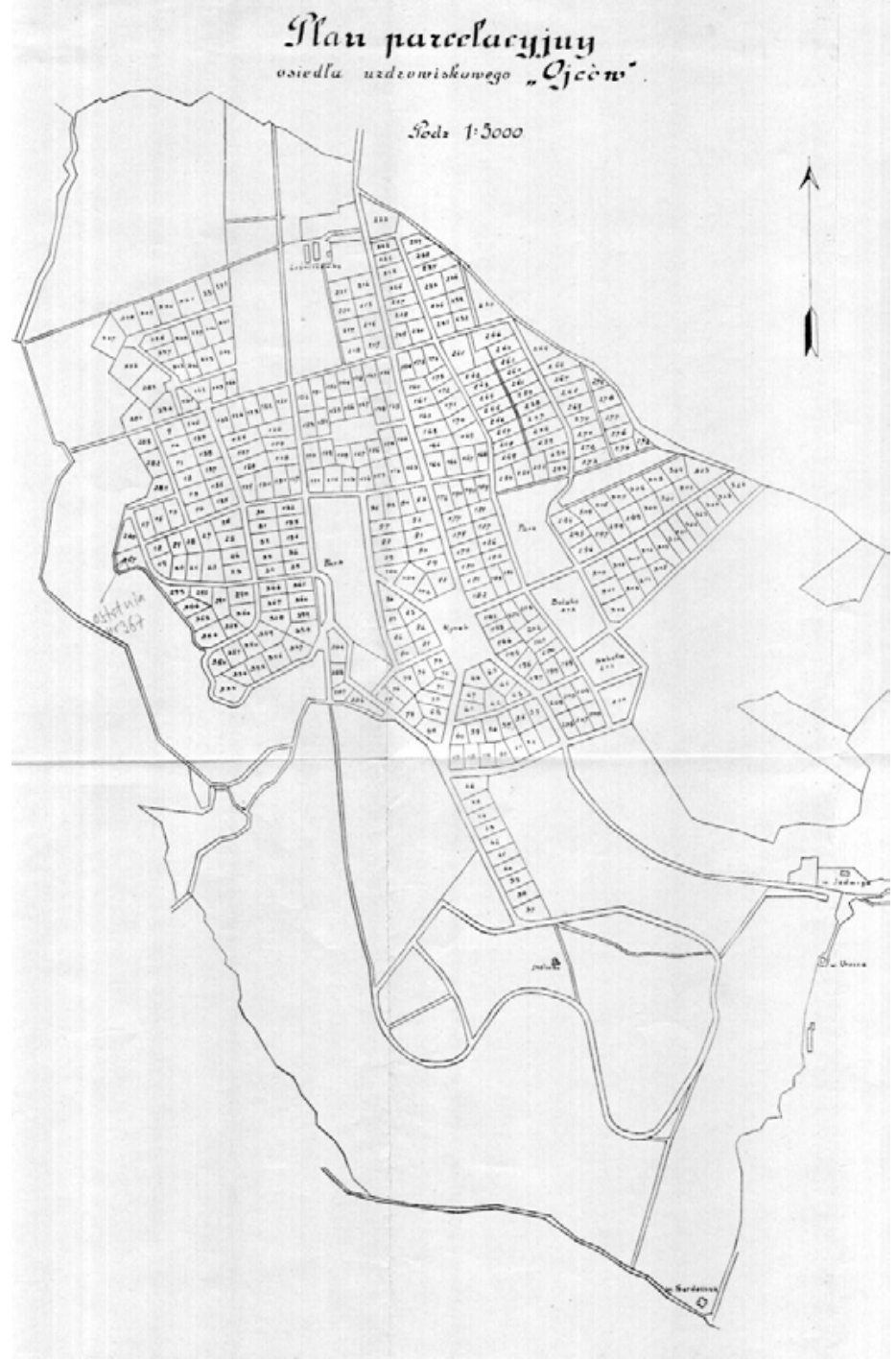

Ryc. 2. Ojców, plan parcelacyjny osiedla uzdrowiskowego, 1:5 000, J. Gałęzowski. [W:] Ojców, broszura reklamowa 1927.

Ojców, plotting plan of the spa development, scale 1:5 000, J. Gałęzowski. [In:] Ojców - publicity leaflet, 1927.

Dla potrzeb sprzedaży działek została przygotowana też mapa również w skali 1:5 000, jednobarwna, gdzie linią jednej grubości zaznaczono parcelację terenu, numery poszczególnych działek i opis terenów wspólnych (rynek, park, boisko). Ta mapa (Ryc. 2) stanowi załącznik do broszury reklamowej (Ojców, 1927). Wszystkich działek jest 367. Ich wielkość waha się od 1500 do $2200 \mathrm{~m}^{2}$. Cena gruntu wynosiła w 1927 r. 3 zł za $1 \mathrm{~m}^{2}$. Wydaje się, że Gałęzowski nie dysponował precyzyjnym pomiarem wysokościowym terenu i tylko intuicyjnie uwzględnił konfigurację jarów na stromym stoku opadającym ku dolinie Prądnika. Stąd parcelacja podlegała zmianom w czasie, z jednej strony - ze względu na konieczność urządzenia dojazdów do działek i dostosowania wielkości 
samych działek do ukształtowania terenu w danym miejscu, z drugiej - na indywidualne życzenia, które prawdopodobnie można było uwzględnić przy sprzedaży.

W tym miejscu należy wspomnieć osobę Mieczysława Majewskiego ${ }^{6}$, wówczas długoletniego dyrektora ośrodka uzdrowiskowo-wypoczynkowego w Ojcowie, który pełnił rolę inicjatora, organizatora i inwestora osiedla uzdrowiskowego na Złotej Górze. Był ważnym partnerem Gałęzowskiego jako projektanta, a o dobrej współpracy obu panów świadczy powtórzenie jej przy projekcie i realizacji osiedla letniskowego w Bukownie.

\section{Realizacja}

W lecie 1927 r. została ukończona budowa drogi z Ojcowa w kierunku zachodnim do Sułoszowej i Olkusza (prowadząca przez teren przyszłego osiedla, jako jego oś). Broszura Ojców (1927) zapowiadała otwarcie do 1 czerwca 1928 r. drogi jezdnej z Krakowa do Ojcowa przez Murownię (Biały Kościół), która obsługiwała Ojców od strony południowej (sławne serpentyny na zjeździe do doliny - odcinek obecnie zamknięty dla ruchu samochodowego). Sieć kanalizacyjna i wodociągowa była budowana w ciągu roku 1928, z wyposażonym w zgrabną glorietkę ujęciem w dolinie Prądnika i zbiornikiem "Jeziorko" na potoku Sąspowskim. Dziś można niespodziewanie natknąć się na studzienki kanalizacyjne w tym rejonie Parku Narodowego. Przewidywano budowę dróg wewnątrz osiedla po zakończeniu budowy tych sieci. Instalacja elektryczna oświetlenia miała być zasilana przez istniejącą już wówczas hydroelektrownię na Prądniku.

Znane są kolejne aktualizacje mapy parcelacji, jak na przykład wersja według stanu na dzień 1 kwietnia 1937 r. $^{7}$, gdzie poszczególne działki zostały oznaczone w kategoriach: 1) sprzedane i przepisane hipotecznie na nabywców; 2) sprzedane lecz akty sprzedaży jeszcze nie zawarte; 3) odkupione od Uzdrowiska Ojców przez X.L. Czartoryską; 4) za zezwoleniem Urzędu Ziemskiego z 1932 roku grunty objęte zezwoleniem Ochrony lasów, które pozostały własnością X. L. Czartoryskiej i sprzedane nie były.

\section{Stan obecny}

Po roku 1945 sprzedaż działek, a również ruch budowlany, zamarły, nie tylko ze względu na trudności powojenne, ale przede wszystkim kwestię prywatnej własności oraz ochronę rezerwatu przyrody. W związku z powstaniem Ojcowskiego Parku Narodowego (OPN) sprzedaż, czy też zabudowa wykupionych działek, po 1956 r. została zabroniona, przy czym dotychczasowi właściciele nadal mogą korzystać z drewna ze swoich działek. Niezależnie od tego OPN prowadzi intensywną akcję wykupu działek, w celu stworzenia jednolitej sytuacji własnościowej na terenie parku narodowego. Można zauważyć, że kolejna aktualizacja mapy 1:5 000, zapewne z lat $50 .{ }^{8}$ zawiera istotne poprawki wynikające z powstania drogi Ojców-Sułoszowa i bardziej precyzyjnego zobrazowania stanu istniejącego (jak np. lokalizacja willi „Lenartówka”). Jest to zapewne nieostatnia wersja w której pojawiają się kategorie: 1) parcele wykupione przez O.P.N.; 2) Parcele przejęte przez Skarb Państwa (Dekret P.K.W.N. z 6.09.1944 r.); 3) Parcele projektowane do wykupu przez O.P.N.; 4) kategoria nieopisana.

Aczkolwiek akcja sprzedaży cieszyła się popularnością (w chwili druku broszury informacyjnej Ojcóww 1927 r. sprzedanych było 167 działek z 367, czyli 45\%, to jednak do wybuchu II wojny światowej zbudowano niewiele. Ze względu na zahamowanie akcji budowlanej zespół pierwotnego osiedla letniskowego nie tworzy żadnego zwartego, czy jednoznacznie skomponowanego zespołu urbanistycznego. Omówione domy stoją osobno. Nie jest możliwe odczytanie planu osiedla w terenie.

W latach 60., wykorzystując scalony teren niezrealizowanego rynku, stworzono w jego miejscu zespół usługowy składający się z pola namiotowego, restauracji, plenerowej sceny oraz dużego parkingu (proj.: arch. M. Łuczyńska-Bruzda i arch. J. Bruzda).

6 M. Majewski był znanym i cenionym działaczem gospodarczo-samorządowym. Po pracy w Ojcowie, przez wiele lat sprawował funkcję Burmistrza m. Olkusza i wówczas był inicjatorem powstania Bukowna jako miejscowości letniskowo-wypoczynkowej. Projektantem tego założenia urbanistycznego był również prof. J. Gałęzowski. Była to koncepcja bardzo dużego przedsięwzięcia - z tym, że po II wojnie światowej została całkowicie zmieniona, gdyż utworzono w Bukownie zaplecze dla Zakładu Górniczo-Hutniczego "Bolesław".

7 Przerys tej mapy zamieszcza w swoim opracowaniu Łuczyńska-Bruzda (1981:17).

8 Odbitka ozalidowa robocza w zbiorach Dyrekcji OPN 


\section{Architektura osiedla}

Nie sposób nie przedstawić, choćby skrótowo, architektury obiektów w ojcowskim osiedlu uzdrowiskowym. W ramach operacji "Osiedle Uzdrowiskowe” powstało zaledwie kilka budynków. „Maria” (rozebrana, widoczne resztki fundamentów) i "Zosia” to dwie duże wielopokojowe wille, które miały służyć na wynajem kuracjuszom. Poza tym powstały prywatne wille, a to: „Gołębiówka”, "Sokołówka”, „Lenartówka”, „Estreicherówka”, „Rój” i willa Kowalskiego (ostatnia wzniesiona budowla, ukończona we wrześniu 1939 r.).

Rola Gałęzowskiego i zakres jego działań projektowych w Ojcowie wymaga dalszych badań. Obok przygotowania projektu parcelacji i zabudowy terenu, bez wątpienia zaprojektował także niektóre z budynków letniskowych. Łuczyńska-Bruzda (1977:11-12) pisze:

„obowiązująca forma domu zaprojektowana przez architekta Józefa Gałęzowskiego [...] nawiązuje do stylu architektury dworkowej prezentowanej w przededniu tych czasów na Wystawie Architektury i Wnętrz w Otoczeniu Ogrodowym w Krakowie w 1912 r. Tu na Złotej Górze powstaje w wersji kamienno-drewnianej, altanowej willi, by w obiektach niektórych domów gospodarczych doliny przejawić się kształtem dachu lub detalem fasad".

Inaczej klasyfikuje budynki Gałęzowskiego Jarosław Żółciak. O "Lenartówce” pisze: "dom wiejski wg projektu prof. J. Gałęzowskiego, o wyraźnie zaznaczających się w stylu echach poszukiwań formy 'narodowej', wpływach funkcjonalizmu i formalnych odniesieniach do budownictwa ... żelbetowego (narożnikowe okna)" ${ }^{\prime 9}$.

Łuczyńska-Bruzda zdaje się sugerować, że Gałęzowski miał wpływ, jeżeli nie osobisty, to pośredni na zabudowę w dolinie, także poza Osiedlem Uzdrowiskowym. Z pewnością natomiast miał kontrolę nad projektami domów w osiedlu. Znając jego podejście z Brześcia Kujawskiego (Lenartowicz 2017), łatwo zauważamy, że poza urbanistyką osiedla zaproponował dwa typy domów mieszkalnych. Prawdopodobnie właściciele działek nie mieli obowiązku realizowania projektów Gałęzowskiego, ale dokumentacja projektowa, jako powtarzalna mogła mieć niższą cenę.

W terenie płaskim pozbawionym spadków Gałęzowski zaprojektował typ budynku na rzucie prostokąta, na kamiennej piwnicy wystającej z terenu, w parterze $z$ dwoma ryzalitami i tarasem skierowanym w stronę wschodnią. Dach czterospadowy (także łamany) z lukarnami i trójspadowym zadaszeniem ganku wejścia głównego, ew. balkonu nad tym wejściem. Charakterystyczną cechą są duże przeszklenia po stronie wschodniej i pełne przeszklenie ryzalitów powyżej parapetu. To dalej niż tylko okna narożnikowe posunięta śmiałość rozwiązania w budowli o konstrukcji drewnianej, zasadniczo wieńcowej. W narożniku pojawia się (oczywiście) słupek konstrukcyjny. Przykładami tego typu są bliźniacze: „Estreicherówka” i „Rój”.

Budowanie na stoku o większym spadku oznacza specyficzne problemy. Dla takich miejsc konieczne było indywidualne opracowanie projektowe. Mimo to można w Ojcowie zauważyć pewną powtarzalność propozycji Gałęzowskiego. Obiekt ma rzut zbliżony do kwadratu, lub wręcz kwadratowy; w centrum komin, który wyprowadzony nad dach zwieńcza całą budowlę (analogicznie do domów w Brześciu Kujawskim). Część przyziemna zrobiona z miejscowego kamienia łamanego (wapień), przy czy ściany przyziemia są nieco pochylone. Od strony gdzie spadek terenu odsłania piwnicę w całości powstaje rodzaj otwartego portyku opartego na kamiennych łukach, które w narożniku spotykają się pod kątem prostym. Łuki są kołowe, założone na wycinku obejmującym ponad połowę okręgu, co dzięki podkowiastemu zarysowi daje efekt nieco mauretański. Przez pochylenie ścian piwnicy narożny filar staje się bardzo krakowską przyporą. Dach czterospadowy łamany, z wystającymi dużymi wybudówkami nakrytymi dachami trójpołaciowymi. Te wybudówki występują ze wszystkich czterech stron budynku. Przykładami tego typu są: „Sokołówka” i „Lenartówka”.

Podsumowując należy zauważyć, że Gałęzowski uczestniczył w Wystawie Architektury i Wnętrze w Otoczeniu Ogrodowym w 1912 r. Jeśli wywarła ona wpływ na jego twórczość, to najbardziej jest to widoczne w domu administracji cukrowni w Brześciu Kujawskim, z tegoż 1912 r. W Ojcowie Gałęzowski idzie dalej, jest

9 Żółciak, J., „Budownictwo uzdrowiskowe na terenie Ojcowskiego Parku Narodowego. Wybrane problemy architektury”. [W:] Zróżnicowanie i przemiany środowiska przyrodniczo-kulturowego Wyżyny Krakowsko-Częstochowskiej. T. 2. Kultura (red.) J. Partyka. Ojcowski Park Narodowy i inni, Ojców 2004, s. 147. 
już zainteresowany nowinkami modernizmu zachodnio-europejskiego. Wprowadza duże przeszklenia, eksperymentuje z oknem narożnikowym i w pełni przeszklonym ryzalitem, co w konstrukcji drewnianej jest trudne i ryzykowne. Miesza konstrukcję sumikowo-łątkową z wieńcową i szkieletową, wprowadza ciesielskie zdobienia w duchu art déco. Swobodnie bawi się materiałem i formą.

W kamiennych łukach prześwitu w przyziemiu widać motyw Stylu Zakopiańskiego, chociaż całość i sam łuk (przez swój zarys) są wyrazem indywidualności twórczej Gałęzowskiego. W rozwiązaniach funkcjonalnych widać doświadczenie z projektowania dworków, ale przeważa oryginalność autorskiego rozwiązania.

Z jego ręki pochodzą więc następujące wille. „Estreicherówka” (1. właściciel: prof. Stanisław Estreicher, rektor UJ), po 1945 r. przeniesiona na Wolę Justowską w Krakowie ${ }^{10}$. W Ojcowie zachował się ledwo widoczny zarys fundamentów. Jej bliźniacza willa "Rój” w Kolencinie w pobliżu leśniczówki (1. właściciel: ?). Obie są wydłużone w rzucie, z dwoma przeszklonymi ryzalitami, skierowanymi na wschód, mają łamane dachy wielopołaciowe.

"Sokołówka" (1. właściciel: Sokołowski, obecny: Bogusław Lachman) oparta w przyziemiu od strony wschodniej na trzech filarach połączonych ze sobą i resztą budynku kamiennymi łukami z lokalnego wapienia przechodzącymi w narożnikowe przypory. Podjazd gospodarczy przewidziany był od strony wschodniej, dzisiaj jedynej zapewniającej dostęp. Oficjalny podjazd (obecnie niemożliwy) i wejście główne oraz tarasy i weranda znajdują się po stronie zachodniej, gdzie pierwotnie istniało otwarcie widokowe na pola uprawne czy łąkę.

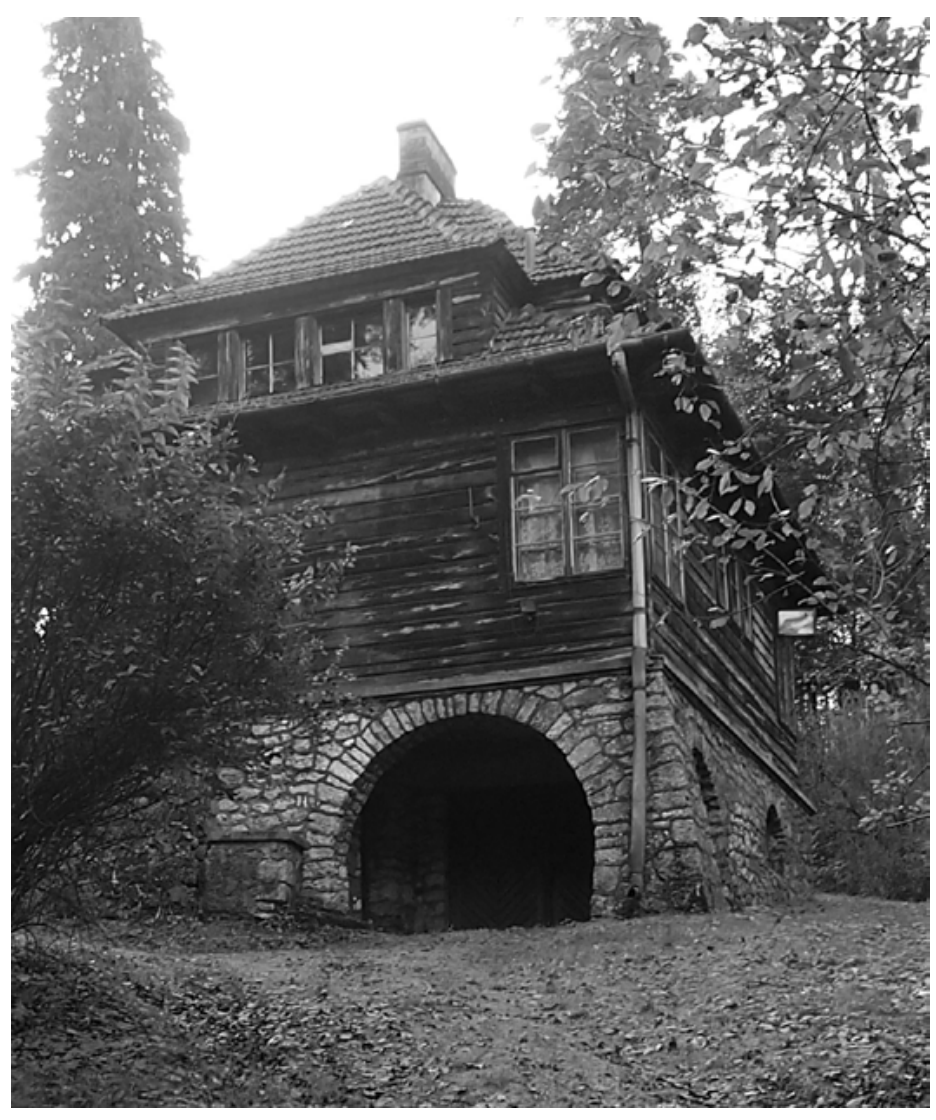

Ryc. 3. Ojców, osiedle uzdrowiskowe, willa „Lenartówka", J. Gałęzowski 1927. Fot. J.-K. Lenartowicz, 2014.

Ojców, spa development, "Lenartówka” villa, J. Gałęzowski, 1927. Photo J.-K. Lenartowicz, 2014.

"Lenartówka" (1. właściciel: prof. Witold Gądzikiewicz, twórca polskiej higieny; 2. - NN Wybult; 3., ostatni właściciel: Józef Lenartowicz - stąd nazwa willi) zbudowana na motywach identycznych do "Sokołówki", ale tutaj znacznie bardziej wyrafinowanych. To najmniejsza willa, zbudowana na rzucie kwadratu, przyziemiem wbita w strome zbocze (Ryc. 3). W związku z tym nie ma osiowości i symetrii, które cechują "Sokołówkę". W wysuniętym

10 Projekt adaptacji budynku i nadzór nad montażem przy ul. Sarnie Uroczysko 15 w Krakowie prowadził arch. Janusz Gawor pod koniec lat 40 Karol Estreicher jun. zapisał willę w spadku Towarzystwu Przyjaciół Sztuk Pięknych w Krakowie, którego był prezesem w latach $1958-1984$ Mieści się tam obecnie Muzeum Rodu Estreicherów, Strat Kultury i Rewindykacji prowadzone przez TPSP. 
narożniku oparta na dwóch prostopadłych do siebie kamiennych łukach przechodzących w narożnikową przyporę. Zewnętrzny taras oparty został na wysokim murze oporowym. Piętro ukryte w dachu nadaje całości wertykalny charakter, usprawiedliwiający żartobliwą nazwę 'Pagoda Gądzikiewicza' nadaną przez sąsiadów. W rzucie parteru wycięty został narożnik południowo-wschodni, co dało osłonięty tarasik przed wejściem do domu ${ }^{11}$. Konstrukcja dachu jest $w$ tym miejscu oparta na pojedynczym słupie. Willa ma kilka wyrafinowanych detali ciesielskich w duchu art déco (dekoracja słupa na tarasie, narożnika przy wejściu z tarasu oraz pseudo-rysi wysuniętych na zewnątrz belek stropowych, które niosą duży okap). Charakterystyczne jest zastosowanie przez Gałęzowskiego narożnikowych okien - motywu przeniesionego z modernistycznych obiektów o konstrukcji żelbetowej, tutaj zrealizowanego w konstrukcji drewnianej mieszanej: wieńcowo-słupowej. Podobne rozwiązania Gałęzowski zastosował też w willach Estreichera i „Raj” na tym osiedlu. O modernistycznych projektach J. Gałęzowskiego pisze Lenartowicz (2014).

"Zosia" (obecnie: dom wycieczkowy kat. III PTTK) jest pensjonatem, co ją odróżnia od prywatnych willi. Zwraca uwagę wyszukanym i zróżnicowanym podziałem skrzydeł okiennych oraz detalem nadproży ceglanych w kamiennym murze z wapienia w kondygnacji parteru. Ma nader złożony układ połaci dachowych, co zdaje się świadczyć o tym, że jej projektantem był Józef Gałęzowski.

„Maria" została rozebrana po utworzeniu OPN, widoczne są ślady fundamentów. Prawdopodobnie pod względem architektonicznym przypominała "Zosię".

"Gołębiówka" (1. właściciel: Gołębiewska; obecnie: jej wnuk Witold Sas Nowosielski) z kamiennym parterem i jedną ścianą szczytową, drewniana, po licznych przeróbkach wewnętrznych, najmniej przypomina rękę Gałęzowskiego.

Ostatnim wzniesionym na terenie osiedla budynkiem willowym jest dom Kowalskiego ${ }^{12}$, położony przy pierwotnie planowanym rynku.

Gałęzowskiemu przypisywane są też dwie wille do niedawna jeszcze stojące przy ul. Zamoyskiego 80 i 83 w Krakowie ${ }^{13}$. Nie można potwierdzić ich pierwotnej lokalizacji w Ojcowie. Można natomiast znaleźć informację, według której zostały one przeniesione do Krakowa w rejon uzdrowiska A. Matecznego jeszcze w okresie międzywojennym. Prace te miały być przeprowadzone w konsultacji z historykiem sztuki Karolem Estreicherem jun., co może wskazywać na źródło zainteresowania późniejszego profesora tego rodzaju domem w Krakowie.

W architekturze samych obiektów z "grupy ojcowskiej" Gałęzowski prowadzi eksperymenty zarówno funkcjonalne (wejście z narożnika, opatrzone słupkiem - wille przy ul. Zamoyskiego, "Lenartówka”) jak i konstrukcyjne (realizacja dużych modernistycznych przeszkleń - ryzality willi Estreichera, czy „Roju”, zapewniające przezierność przez cztery, nanizane na oś patrzenia, okna (Lenartowicz 2014).

\section{Podziękowania}

Powstanie tego artykułu nie byłoby możliwe bez życzliwej przychylności kilku osób. Podziękowania za pomoc autor kieruje do Witolda Sasa Nowosielskiego w Ojcowie oraz Józefa Partyki i Jarosława Żółciaka z Dyrekcji Ojcowskiego Parku Narodowego.

11 To charakterystyczny dla Gałęzowskiego motyw, występujący także w dwóch willach jego projektu przy ul. Zamoyskiego w Krakowie (rozebranych doszczętnie w 2015 r.).

12 Obiekt o innej architekturze - modernistyczna kostka o charakterystycznym skromnym detalu i płaskim dachu o niewielkim spadku w stronę zachodnią. Budynek powstał we wrześniu 1939 r. Jego projektantem był inż. Rumianowski. W r. 1954 r. na tej samej działce został wzniesiony budynek gospodarczy (dla pszczół) o wydłużonym wąskim rzucie przekryty dachem czterospadowym, z wyższą i szerszą częścią centralną przekrytą dachem namiotowym czteropołaciowym. Ten „ul” jest ostatnią budowlą mieszkalną, jaka została wzniesiona w OPN.

13 W Internecie można znaleźć nieudokumentowaną informację, że budynki przy ul. Zamoyskiego zostały sprowadzone być może z Lanckorony o czym miałby świadczyć kształt dachu (naczółkowy). Oba obiekty miały być własnością obywateli polskich narodowości żydowskiej i służyć pracownikom tartaku w Krakowie. W późniejszych latach użytkowano je jako mieszkania komunalne. Według innych informacji wille zostały zbudowane w Podgórzu jako mieszkania socjalne dla pracowników Kamieniołomu Libana. 


\section{Literatura}

[1] Lenartowicz, J.-K. (2013), "Józef Gałęzowski, architekt-artysta, nauczyciel" [W:] B. Bartkowicz (red.) 90-lecie istnienia Towarzystwa Urbanistów Polskich w Krakowie 1923-2013. Politechnika Krakowska, TUP O/Kraków, Komisja AiU O/PAN Kraków, s. 46-56.

[2] Lenartowicz, J.-K. (2014), "Józef Gałęzowski - modernista?" [W:] M. J. Sołtysik i R. Hirsch (red.) Modernizm w Europie. Modernizm w Gdyni. Architektura XX w. i jej waloryzacja. Urząd Miasta Gdyni, Gdynia (w druku).

[3] Lenartowicz, J.-K. (2017), „The Urban Design and Planning Activity of Professor Józef Gałęzowski between 1912 and 1918 / Działalność planistyczna i urbanistyczna profesora Józefa Gałęzowskiego w latach 1912-1918" [W:] E. Węcławowicz-Bilska (red.) New Ideas in Planning for Territorial Development. Vol. I: New concepts of urban planning and spatial planning. Politechnika Krakowska, Kraków 2017, monografia 545, s. 37-56.

[4] Łuczyńska-Bruzda, M., „Raport o stanie budownictwa w Ojcowskim Parku Narodowym”. Kraków 1976-1977. Maszynopis powielany.

[5] Łuczyńska-Bruzda, M., Skuteczność planowania przestrzennego Ojcowskiego Parku Narodowego. Politechnika Krakowska, Kraków 1981.

[6] Mitkowska, A., "Uzdrowisko w Ojcowie i jego park zdrojowy”. [W:] PRĄDNIK. Prace i materiały Muzeum im. Prof. W. Szafera. T. 10, (red.) K. Grodziska i J. Partyka, 1995, s. 105-134.

[7] Nowak, J., "Ojców za Zawiszów, Krasińskich i Czartoryskich 1878-1945". [W:] Zróżnicowanie i przemiany środowiska przyrodniczo-kulturowego Wyżyny Krakowsko-Częstochowskiej. T. 2. Kultura. J. Partyka (red.). Ojcowski Park Narodowy i inni, Ojców 2004, s. 119-132.

[8] Ojców. Komitet Rozbudowy Osiedla Uzdrowiskowego Ojców, Kraków 1927. Broszura reklamowa z planem parcelacyjnym 1:5000.

[9] Partyka, J.; Żółciak, J., „Dziedzictwo kulturowe Ojcowskiego Parku Narodowego”. [W:] Ochrona dóbr kultury i historycznego związku człowieka z przyrodą w parkach narodowych. Ojcowski Park Narodowy, Ojców 2003, s. 353-364.

[10] Partyka J. (red.) Zróżnicowanie i przemiany środowiska przyrodniczo-kulturowego Wyżyny Krakowsko-Częstochowskiej. T. 2. Kultura. Ojcowski Park Narodowy i inni, Ojców 2004.

[11] PRĄDNIK. Prace i materiały Muzeum im. Prof. W. Szafera. Tom 10. (red.) Karolina Grodziska i J. Partyka. OPN, Ojców 1995.

[12] Sadowska, E. i Żółciak, J., „Willa Lenartówka”. Biała karta ewidencyjna zabytku architektury i budownictwa. 12 X 1990.

[13] Zgórniak, M., Gałęzowski Józef. [Hasło w:] Allgemeines Künstler-Lexicon, Band 47, München-Leipzig 2005, s. $452-453$.

[14] Żółciak, J., „Budownictwo uzdrowiskowe na terenie Ojcowskiego Parku Narodowego. Wybrane problemy architektury”. [W:] Zróżnicowanie ... (red.) J. Partyka, 2004, s. 145-154.

Abstract: Professor Józef Gałęzowski (1877-1963) was an eminent representative of Cracow architecture. Beside many important architectural projects and realizations, he was the author of several larger spatial developments, presented in this paper. During the WW I he published his reconstruction projects $(1915,1916)$ of Polish villages and towns. Gałęzowski planned to take advantage of war destruction to raise standard of housing conditions, and propagated the idea by organizing an itinerant exhibition of drawings and maquettes accompanied by public lectures. He also founded the Office of Towns' Regulation in Cracow and Lvov (1917). Gałęzowski altogether designed the following developments, which partially had been realized: workers development in Brześć Kujawski (1912), spa development in Ojców (1927), workers development in Majdan near Stanisławów (today: Ukraine), and summer development in Bukowno (1933), all based on the garden city model.

Key words: Józef Gałęzowski, Ojców, spa development, garden city 